\title{
Toxicologic Evaluation of Analytes from Tank 241-C-103
}

D. D. Mahlum, Ph.D.

J. Y. Young, C.I.H.

R. E. Weller, D.V.M.

November 1994

Prepared for the U.S. Department of Energy under Contract DE-AC06-76RLO 1830

Pacific Northwest Laboratory Operated for the U.S. Department of Energy by Battelle Memorial Institute 


\title{
DISCLAIMER
}

This report was prepared as an account of work sponsored by an agency of the United States Government. Neither the United States Government nor any agency thereof, nor Battelle Memorial Institute, nor any of their employees, makes any warranty, expressed or implied, or assumes any legal liability or responsibility for the accuracy, completeness, or usefulness of any information, apparatus, product, or process disclosed, or represents that its use would not infringe privately owned rights. Reference herein to any specific commercial product, process, or service by trade name, trademark, manufacturer, or otherwise does not necessarily constitute or imply its endorsement, recommendation, or favoring by the United States Government or any agency thereof, or Battelle Memorial Institute. The views and opinions of authors expressed herein do not necessarily state or reflect those of the United States Government or any agency thereof.

\author{
PACIFIC NORTHWEST LABORATORY \\ operated by \\ BATTELLE MEMORIAL INSTITUTE \\ for the \\ UNITED STATES DEPARTMENT OF ENERGY \\ under Contract DE-AC06-76RLO 1830
}

Printed in the United States of America

Available to DOE and DOE contractors from the

Office of Scientific and Technical Information, P.O. Box 62, Oak Ridge, TN 37831; prices available from (615) 576-8401. FTS 626-8401.

Available to the public from the National Technical Information Service, U.S. Department of Commerce, 5285 Port Royal Rd., Springfield, VA 22161. 
PNL-10189

UC-607

\section{Toxicologic Evaluation of Analytes From Tank 241-C-103}

D. D. Mahlum, $\mathrm{PhD}$

J. Y. Young, $\mathrm{CIH}$

R. E. Weller, DVM

November 1994

Prepared for

the U.S. Department of Energy

under Contract DE-AC06-76RLO 1830

Pacific Northwest Laboratory

Richland, Washington 99352 



\section{Foreword}

This document summarizes the collective contributions of the Toxicology Review Panel (TRP) in the evaluation of toxicologic implications of the analytes from Tank 241-C-103. Members of the TRP are as follows:

D. Dennis Mahlum, $\mathrm{PhD}$ (chair)

John Y. Young, MSPH, CIH (co-chair)

Antone L. Brooks, PhD

John A. Calcagni, MD

Jeffrey A. Dill, $\mathrm{PhD}$

Barbara L. Harper, PhD, DABT

Thomas W. Henn, JD, MD

Mary F. Jarvis, PhD

James E. Morris, PhD

David L. Springer, PhD, DABT

Brian D. Thrall, PhD

Richard E. Weller, DVM

The TRP appreciates the proactive interest of the U.S. Department of Energy in the health and safety of workers in the Hanford tank farms. The TRP also wishes to acknowledge the excellent support provided by Steven C. Goheen, PhD, Program Manager, Pacific Northwest Laboratory (PNL), Jerry W. Osborne, Program Manager, Westinghouse Hanford Company (WHC), James L. Huckaby, $\mathrm{PhD}$, WHC, and all the personnel involved in the Tank Vapor Sampling Program. 



\section{Summary}

Westinghouse Hanford Company requested PNL to assemble a toxicology review panel (TRP) to evaluate analytical data compiled by WHC, and provide advice concerning potential health effects associated with exposure to tank-vapor constituents. The team's objectives would be to 1) review procedures used for sampling vapors from tanks, 2) identify constituents in tank-vapor samples that could be related to symptoms reported by workers, 3 ) evaluate the toxicologic implications of those constituents by comparison to established toxicologic databases, 4 ) provide advice for additional analytical efforts, and 5) support other activities as requested by WHC. The TRP represents a wide range of expertise, including toxicology, industrial hygiene, and occupational medicine.

The TRP prepared a list of target analytes that chemists at the Oregon Graduate Institute/Sandia (OGI), Oak Ridge National Laboratory (ORNL), and PNL used to establish validated methods for quantitative analysis of head-space vapors from Tank 241-C-103. This list was used by the analytical laboratories to develop appropriate analytical methods for samples from Tank 241-C-103. Target compounds on the list included acetone, acetonitrile, ammonia, benzene, 1,3-butadiene, butanal, n-butanol, hexane, 2-hexanone, methylene chloride, nitric oxide, nitrogen dioxide, nitrous oxide, dodecane, tridecane, propane nitrile, sulfur oxide, tributyl phosphate, and vinylidene chloride.

Samples for analysis of vapors from Tank 241-C-103 were obtained via methods including OSHA versatile sampling (OVS) tubes (analyzed by PNL), SUMMA ${ }^{\mathrm{TM}}$ canisters (analyzed by OGI and PNL), and triple-sorbent tubes (TSTs; analyzed by ORNL). The semiquantitative data provided by these laboratories served as the basis for April 1994 TRP recommendations. In general, the compounds designated for further investigation met criteria stated in the Data Quality Objectives (DQO) document for Tank 241-C-103 (Osborne et al. 1994); namely, that when the concentration of a compound exceeds one-half of the consensus exposure standard for systemic toxins or one-tenth of the standard for carcinogens, mutagens, or teratogens, the WHC Industrial Hygiene Group is to be advised.

The TRP considered constituent concentrations, current exposure limits, reliability of data relative to toxicity, consistency of the analytical data, and whether the material was carcinogenic or teratogenic. A final consideration in the analyte selection process was to include representative chemicals for each class of compounds found.

The Tank Vapor Conference IV (Richland, Washington, March 8-9, 1994) resulted in improvements for sampling equipment and procedures. Sample Job 7B (SJ7B), was performed to quantitate the target analytes identified in the previous sampling, and to serve as the basis for a definitive evaluation of the toxicologic implications of vapors in Tank 241-C-103. Analysis of SJ7B revealed the same constituents as the previous sampling except no dodecane or tridecane were found, although n-tridecane was present. There was good agreement between the values obtained from the different laboratories using a variety of methods. The following conclusions were made:

Concentrations of acetone, hexane, nitric oxide, nitrogen dioxide, sulfur dioxide, butanal, and vinylidene chloride should not raise unacceptable toxicologic concern. Ammonia, nitrous oxide, tributyl phosphate, acetonitrile, n-butanol, 2-hexanone, propane nitrile, benzene, methylene chloride, NPHs, and 1,3-butadiene are present in concentrations large enough to warrant further consideration, although methylene chloride may be an artifact. 
Due to lack of consensus exposure standards for butanal and the NPHs, particularly dodecane and tridecane, the TRP determined that NPHs be treated as a group and that consensus exposure standards for dodecane and tridecane be set at $120 \mathrm{ppm}$, and a consensus exposure standard for butanal be set at $50 \mathrm{ppm}$.

The WHC Industrial Hygiene Group should develop an exposure assessment strategy that includes, at a minimum, area and personal sampling, hazard communication and training, medical monitoring, and record-keeping. Documentation of the exposure assessment strategy will be critical. Appropriate personal protection should be used by workers in the tank farm areas. This Group also should consider mitigation strategies to prevent potential release of these chemicals into the environment. Meteorological data should be continuously monitored when personnel are working in the immediate area of the tank or when exposure sampling is performed. A method for using sentinel compounds to monitor potential worker exposure is suggested.

The presence of many other compounds in addition to the target list should not be ignored; however, clarification of any biological effects will require additional efforts, as the potential toxicity of mixtures of chemicals cannot be accurately predicted from chemical characterization alone. Until actual biological characterization of tank vapors is performed, there will always be uncertainty about the contributions of unidentified constituents as well as the interaction of the chemicals on biological systems. The TRP recommends studies be undertaken to biologically characterize vapors from Tank 241-C-103 to ensure that they do not produce unexpected toxic effects. Initial screening studies can be performed in cellular systems, providing some indication of a hitherto unidentified component or interaction among components in a biological system. 


\section{Contents}

Foreword $\ldots \ldots \ldots \ldots \ldots \ldots \ldots \ldots \ldots \ldots \ldots \ldots \ldots \ldots \ldots \ldots \ldots \ldots$

Summary $\ldots \ldots \ldots \ldots \ldots \ldots \ldots \ldots \ldots \ldots$

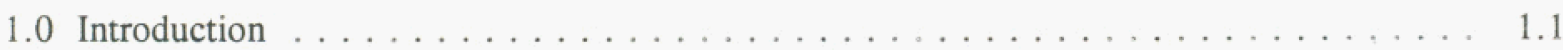



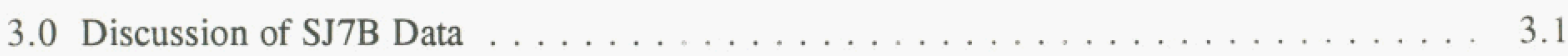

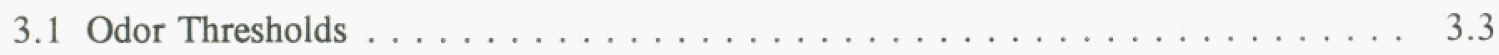

3.2 Rationale for Using $\mathrm{LD}_{50}$ and $\mathrm{LC}_{50}$ to Evaluate Toxicity Potentials $\ldots \ldots \ldots .3$

4.0 Toxicologic Implications of Tentatively Identified Chemicals $\ldots \ldots \ldots \ldots . \ldots$

5.0 Applicable Industrial Hygiene Considerations $\ldots \ldots \ldots \ldots \ldots \ldots \ldots \ldots \ldots \ldots$

5.1 Sample Selected Chemicals $\ldots \ldots \ldots \ldots \ldots \ldots \ldots \ldots \ldots \ldots \ldots \ldots$

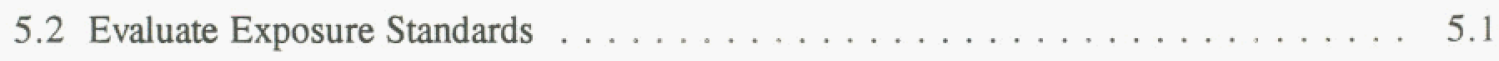

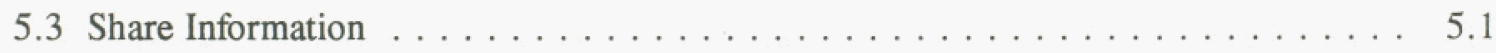

5.4 Protect Against (Skin-Designated) Chemicals . . . . . . . . . . . . 5.1

5.5 Consider Ambient Conditions that May Affect Personnel Exposure . . . . . . . . . 5.2

6.0 Sentinel Compounds . . . . . . . . . . . . . . . . . . . . 6.1

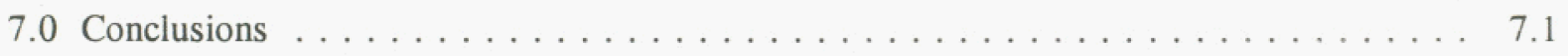

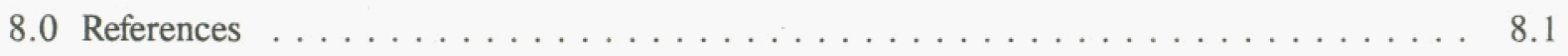




\section{Tables}

2.1 Analytes from Tank $241-\mathrm{C}-103$ Recommended for Quantitation $\ldots \ldots \ldots \ldots \ldots . .2$

3.1 Data from Sample Job 7B for Compounds of Toxicologic Concern

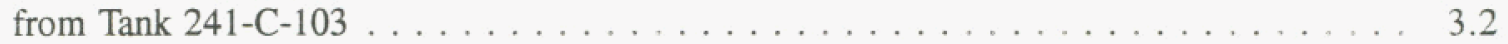

3.2 Odor Thresholds and Descriptions on Tank 241-C-103 Target Analytes $\ldots \ldots \ldots \ldots .4$

6.1 Use of Sentinel Compounds to Monitor for Carcinogens in Vapor

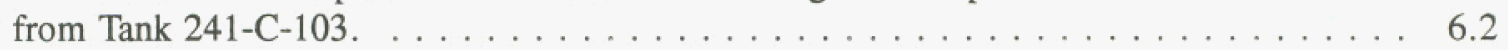

7.1 Summary List of Targeted Chemicals for Toxicologic Evaluation as of

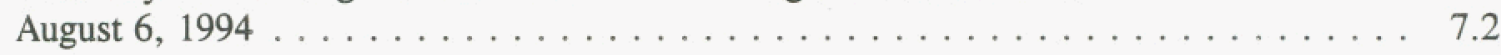




\subsection{Introduction}

A number of people have reported ill effects, including headaches, burning sensation in nose and throat, nausea, and impaired pulmonary function, while working around waste tanks on the Hanford Site. As indicated in the 1993 Program Plan for the Resolution of Tank Vapor Issues (Osborne and Huckaby 1994), musty and foul odors, including the smell of ammonia, have been reported to emanate from several single-shelled tanks. During the period between July 1987 and May 1992, 27 workers were involved in 16 complaints of exposures to odors. Ten of these occurrences, involving 18 workers, were linked to the C Tank Farm. In particular, Tank $241-\mathrm{C}-103$ was implicated in six of the reports, with 12 workers sustaining lost time. [For a brief history of Tank 241-C-103, see Mahlum and Young (1993).]

Westinghouse Hanford Company (WHC) requested Pacific Northwest Laboratory (PNL) ${ }^{(a)}$ to assemble a toxicology team to independently review analytical data and provide advice concerning potential health effects associated with exposure to tank-vapor constituents. The team's objectives were to 1) review procedures used for sampling vapors from various tanks, 2) identify constituents in tankvapor samples that could be related to symptoms reported by waste-tank workers, 3) evaluate the toxicologic implications of those constituents by comparison to established toxicologic data bases, 4) provide advice for additional analytical efforts, and 5) support other activities as requested by the project manager and the cognizant WHC Tank Vapor Issues Safety Resolution Manager.

A Toxicology Review Panel (TRP) was constituted during FY 1993 to help with these objectives. In particular, the TRP was to identify and recommend compounds of toxicologic concern for quantitative analysis by validated methodology, with the quantitation extending to levels well below established exposure standards. The panel is composed primarily of staff from PNL's Life Sciences Center, and occupational medical doctors from the Hanford Environmental Health Foundation (HEHF). The TRP was designed to represent a wide range of expertise, including analytical chemistry, industrial hygiene, occupational medicine, genetic and general toxicology, immunology, and radiation biology.

The TRP was requested by WHC and Northwest Instrument Systems Inc. (NISI) to prepare a list of analytes that chemists at Oregon Graduate Institute/Sandia (OGI), Oak Ridge National Laboratory (ORNL), and PNL could use to establish validated methods for quantitative analysis of head-space vapors from Tank 241-C-103. The TRP also was asked to recommend the levels at which the laboratories should be able to analyze the compounds. A preliminary list was developed using two sets of existing data, one each from analyses performed by PNL and OGI. Although these previous samplings and analyses were obtained using nonvalidated methodology, both sets of data showed the presence of n-butanol, acetone, acetic acid, normal paraffin hydrocarbons (NPHs) with their alcohol and ketone derivatives, aromatic hydrocarbons, and several chlorinated hydrocarbons. In addition, the PNL data indicated the presence of significant concentrations of ammonia, tributyl phosphate, and nitrogen oxides in the head-space vapor. A list of analytes was prepared based on 1) the concentrations reported

(a) Pacific Northwest Laboratory is a multiprogram national laboratory operated by Battelle Memorial Institute for the U.S. Department of Energy under Contract DE-AC06-76RLO 1830. 
by PNL and OGI, 2) the toxicity of the compounds (especially if potential carcinogenic activity was reported for a compound), and 3 ) the need to solidify the data on potential classes of compounds. This list was used by the analytical laboratories to begin development of appropriate analytical methods in preparation for receipt of samples from Tank $241-\mathrm{C}-103$ that would be provided by WHC. 


\subsection{TRP Activities in FY 1994}

Samples for analysis of vapors from Tank 241-C-103 were obtained by WHC using a number of sampling methods including Occupational Safety and Health Administration (OSHA) versatile sampling (OVS) tubes, SUMMA ${ }^{\mathrm{TM}}$ canisters, and triple-sorbent tubes (TSTs). A sampling performed in December 1993 and January 1994, Sample Job 6B (SJ6B), provided data for an initial TRP review in April 1994. The OVS tubes were analyzed by PNL, the SUMMA ${ }^{\mathrm{TM}}$ canister samples by OGI and PNL, and the TSTs by ORNL. The analyses of ammonia, nitrogen oxides, and sulfur oxides also were performed by PNL.

The semiquantitative data provided by these laboratories were presented at Tank Vapor Conference IV, Richland, Washington, March 8-9, 1994, and served as the basis for the April 1994 TRP recommendations. These recommendations consisted of a list of constituents for which quantitative methods were to be established and validated (April 13, 1994, letter from S.C. Goheen to J.W. Osborne); many constituents were the same as suggested in the preliminary list mentioned previously (Mahlum and Young 1993). In general, the compounds designated for further investigation met criteria stated in the Data Quality Objectives (DQO) document for Tank 241-C-103 (Osborne et al. 1994). The DQO specifies that when the concentration of a compound exceeds one-half of the consensus exposure standard for systemic toxins or one-tenth of the standard for carcinogens, mutagens, or teratogens, the WHC Industrial Hygiene Group is to be advised. This stipulation helps guide the group in selecting methods for area and personnel monitoring on the tank farms.

The TRP considered constituent concentrations, current exposure limits, reliability of data relative to toxicity, consistency of the analytical data, and whether the material was carcinogenic or teratogenic. A final consideration in the analyte selection process was to include representative chemicals for each class of compounds found. The result is that representatives for NPHs, nitriles, ketones, aldehydes, halogenated hydrocarbons, alcohols, aromatics, and inorganics were included on the list. Sulfur oxides were added to the list because earlier data had suggested their presence. From the list of analytes reported from SJ6B, the TRP selected the materials shown in Table 2.1.

In addition to the analytical data presented, attendees at Tank Vapor Conference IV identified improvements to be made in the sampling equipment and procedures. Subsequently, two additional samplings (Sample Jobs 7A and 7B) were performed on Tank 241-C-103. Sample Job 7B (SJ7B) was performed to quantitate the target analytes identified from SJ6B, and to serve as the basis for a definitive evaluation of the toxicologic implications of vapors in Tank 241-C-103.

The data from SJ7B have been summarized (Table 3.1) by Huckaby and Story (1994). The results were presented and discussed at Tank Vapor Conference V on July 18 and 19, 1994, in Richland, Washington. The TRP has used these data for the evaluation presented in this report. 
Table 2.1. Analytes from Tank 241-C-103 Recommended for Quantitation

\begin{tabular}{|c|c|c|c|c|c|c|c|c|c|}
\hline \multirow{3}{*}{ Compound } & \multirow{3}{*}{ CAS } & \multicolumn{6}{|c|}{ Exposure Limits (ppm) } & \multirow{3}{*}{ CES* } & \multirow{3}{*}{ Health Effects } \\
\hline & & \multicolumn{2}{|c|}{ NIOSH REL } & \multicolumn{2}{|c|}{ ACGIH TLV } & \multicolumn{2}{|c|}{ OSHA PEL } & & \\
\hline & & 8-hr TWA & STEL & 8-hr TWA & STEL & 8-hr TWA & Others & & \\
\hline Acetone & $67-64-1$ & 250 & & 750 & 1000 & 1000 & & & $\begin{array}{c}\text { Narcosis; CNS depression; eye, nose, } \\
\text { throat and skin irritation }\end{array}$ \\
\hline Acetonitrile & $75-05-8$ & 20 & & 40 & 60 & 40 & & & Brain tumors; lung and bowel cancer \\
\hline Ammonia & $7664-41=7$ & 25 & 35 & 25 & 35 & 50 & & & Respiratory and eye irritation \\
\hline Benzene & $71-43-2$ & $0.1 / \mathrm{LOQ}$ & 1 (c) $(15 \mathrm{~min})$ & $0.1 * *(A 2)$ & & $10 / 25(\mathrm{c})$ & $50(10 \mathrm{~min})(\mathrm{p})$ & & Leukemia \\
\hline 1,3-Butadiene & $106-99-0$ & $0.19 / \mathrm{LOQ}$ & & $2 * *(A 2)$ & & 1000 & & & $\begin{array}{c}\text { Hematopoietic cancer; teratogenic and } \\
\text { reproductive effects }\end{array}$ \\
\hline Butanal & $123-72-8$ & & & & & & & 50 & $\begin{array}{c}\text { Eye, nose, throat, and skin irritant. } \\
\text { Insufficient information on chronic } \\
\text { effects }\end{array}$ \\
\hline $\mathrm{n}$-Butanol & $71-36-3$ & $50(\mathrm{c})(\mathrm{s})$ & & $50(\mathrm{c})(\mathrm{s})$ & & $100(s)$ & & & $\begin{array}{c}\text { Eye and mucous membrane irritation; } \\
\text { CNS depression }\end{array}$ \\
\hline Hexane & $110-54-3$ & 50 & & 50 & & 500 & & & Skin and nervous system effects \\
\hline $\begin{array}{c}\text { 2-Hexanone } \\
(\mathrm{MnBK})\end{array}$ & $591-78-6$ & 1 & & $5(s)$ & & 100 & & & $\begin{array}{l}\text { Irritation; liver, kidney, and nervous } \\
\text { system effects }\end{array}$ \\
\hline $\begin{array}{l}\text { Methylene } \\
\text { chloride }\end{array}$ & $75-09-2$ & LOQ & & $50(\mathrm{~A} 2)$ & & 100 & & & $\begin{array}{l}\text { Potential for cancer; tumors of the lung, } \\
\text { liver, salivary, and mammary glands in } \\
\text { animals }\end{array}$ \\
\hline Nitric oxide & $10102-43-9$ & 25 & & 25 & & 25 & & & Effects on blood and respiratory system \\
\hline \begin{tabular}{|l|} 
Nitrogen dioxide \\
\end{tabular} & $10102-44-0$ & & 1 & 3 & & & $1(\mathrm{c})$ & & Respiratory and blood effects \\
\hline Nitrous oxide & $10024-97-2$ & & $25 * * *$ & 50 & & $500 / 1000(\mathrm{c})$ & $2000(5 \mathrm{~min}$ in $2 \mathrm{hr})(\mathrm{p})$ & & $\begin{array}{l}\text { Reproductive system effects and } \\
\text { decreases in audiovisual performance }\end{array}$ \\
\hline Dodecane & $112-40-3$ & & & & & & & 120 & Skin and nervous system effects \\
\hline Tridecane & $629-50-5$ & & & & & & & 120 & Skin and nervous system effects \\
\hline Propane nitrile & $107-12-0$ & 6 & & & & & & & $\begin{array}{l}\text { Hepatic, renal, respiratory, } \\
\text { cardiovascular, gastrointestinal, and } \\
\text { nervous system effects }\end{array}$ \\
\hline Sulfur oxide & $7446-09-5$ & 2 & 5 & 2 & 5 & 5 & & & Respiratory effects \\
\hline Tributyl phosphate & $126-73-8$ & 0.2 & & 0.2 & & 0.66 & & & $\begin{array}{c}\text { Pulmonary irritation; moderate } \\
\text { excitation of nervous system in animals }\end{array}$ \\
\hline $\begin{array}{l}\text { Vinylidene } \\
\text { chloride }\end{array}$ & $75-35-4$ & $0.4 / \mathrm{LOQ}$ & & 5 & 20 & & & & $\begin{array}{l}\text { Potential for cancer; liver and kidney } \\
\text { tumors in animals }\end{array}$ \\
\hline
\end{tabular}

* No established exposure limit; CES values as proposed by TRP

** Proposed for intended changes

** For the duration of exposure

A2 Suspected human carcinoger

(c) Ceiling

(s) Skin designation

(p) Peak concentration

ACGIH TLV American Conference of Governmental Industrial Hygenists threshold limit value

CAS Chemical Abstract Service

CES Consensus exposure standard

LOQ Limit of quantitation. For carcinogenic materials, NIOSH recommends LOQ as the desired limit.

NIOSH REL National Institute for Occupational Safety and Health recommended exposure limit

OSHA REL Occupational Safety and Health Administration permissible exposure limit

Sources: Title 29 CFR 1910

ACGIH 1993

NIOSH 1977,1992 


\subsection{Discussion of SJ7B Data}

The data in Table 3.1, in general, show fairly good agreement between values from different laboratories for those materials collected and analyzed by more than one method. This agreement gives confidence that the data closely reflect the actual content of the tank. This confidence is further strengthened by the similarity in results obtained for NPH from OVS tubes lowered into the tanks and from samples of the vapor sampling system. These results also suggest that both the sampling procedures and the analytical procedures are being well-controlled.

The concentrations of several constituents fell below the level of concern defined previously. Acetone, hexane, nitrogen oxide, nitrogen dioxide, and sulfur oxides did not exceed one-half of the exposure standard for systemic toxins, and the level of vinylidene chloride fell below one-tenth of the exposure standard. The other compounds on the list, however, are in sufficient concentrations that they merit continued consideration. Concentrations of ammonia, nitrous oxide, and tributyl phosphate all exceeded the actual exposure standards, while values for acetonitrile, n-butanol, 2-hexanone, and propane nitrile were greater than $50 \%$ of the exposure standards. These compounds should be considered by WHC management and industrial safety staff relative to the selection of methods for area and personnel monitoring, personal protective equipment, and mitigation strategies on the tank farms. Although values for benzene, 1,3-butadiene, and methylene chloride were very low, they are considered carcinogens and exposure should be minimized. Methylene chloride was used to clean the sampling equipment; therefore, the levels found may not be due to material in the tank but to extremely low residual levels in the sampling apparatus.

A third group of materials includes the NPHs (dodecane and tridecane) and butanal (butyraldehyde), for which no exposure standards have been established. However, the TRP considered exposure standards for similar compounds to recommend levels of potential concern by analogy. For example, the recommended exposure limits (RELs) for heptane, octane, and nonane are 85, 75, and 200 parts per million (ppm), respectively. An average of the RELs for these three materials is $120 \mathrm{ppm}$; combining values for dodecane and tridecane would result in a value greater than $50 \%$ of the average, suggesting that attention should be given to the NPH as a class.

Because butanal also does not have an established exposure limit, we examined exposure limit values for similar types of compounds, i.e. other short-chain aldehydes. Data for propanal, pentanal, and hexanal were examined because they constitute the homologous compounds on each side of the compound of interest.

Values for the lethal dose for $50 \%$ of the experimental animals $\left(\mathrm{LD}_{50}\right)$, a gross measure of toxicity, are similar for propanal, butanal, and pentanal. The oral $\mathrm{LD}_{50}$ values of approximately $5 \mathrm{~g} / \mathrm{kg}$ body weight are indicative of low acute toxicities. When the materials are administered at toxic levels, all three produce mild central nervous system depression. All the chemicals have been reported negative in tests for mutagenicity (Sax and Lewis 1989). Thus, the three compounds appear to be similar in their toxicologic properties. Although there is no established exposure limit for propanal, an REL of 
Table 3.1. Data from Sample Job 7B for Compounds of Toxicologic Concern from Tank 241-C-103

\begin{tabular}{|c|c|c|c|c|c|}
\hline $\begin{array}{l}\text { Chemical } \\
\text { (CAS\#) }\end{array}$ & $\begin{array}{c}\text { Reported } \\
\text { Concentration } \\
(\mathrm{ppm}) \\
\end{array}$ & $\begin{array}{l}\text { IDLH } \\
(\mathrm{ppm}) \\
\end{array}$ & $\begin{array}{c}\text { IDLH } \\
\text { Concern } \\
\end{array}$ & $\begin{array}{c}1 / 2 \text { or } 1 / 10 \\
\text { CES* }(\mathrm{ppm}) \\
\end{array}$ & $\begin{array}{c}\text { Retain on } \\
\text { List }\end{array}$ \\
\hline $\begin{array}{l}\text { Acetone } \\
(67-64-1)\end{array}$ & $\begin{array}{l}19.2-19.4 \\
8.8\end{array}$ & 20,000 & no & $\overline{125}$ & $\overline{\overline{\text { no }}}$ \\
\hline $\begin{array}{l}\text { Acetonitrile } \\
(75-05-8)\end{array}$ & $\begin{array}{c}12.7-13.2 \\
9.1\end{array}$ & 4,000 & no & 10 & yes \\
\hline $\begin{array}{l}\text { Ammonia } \\
(7664-41-7)\end{array}$ & 304 & 500 & maybe & 12.5 & yes \\
\hline $\begin{array}{l}\text { Benzene** } \\
(71-43-2)\end{array}$ & $\begin{array}{c}<0.01-0.33 \\
0.08\end{array}$ & 1,000 & no & 0.01 & yes \\
\hline $\begin{array}{l}1,3-\text { Butadiene } \\
(106-99-0)\end{array}$ & $<0.05-0.06$ & $20,000(\mathrm{LEL})$ & no & 0.019 & yes \\
\hline $\begin{array}{l}\text { Butanal } \\
(123-72-8)\end{array}$ & $\begin{array}{c}4.4-4.7 \\
1.2 \\
\end{array}$ & & $?$ & 25 & no \\
\hline $\begin{array}{l}\text { n-Butanol } \\
(71-36-3)\end{array}$ & $\begin{array}{l}13.1 \\
28.4\end{array}$ & 8,000 & no & 25 & yes \\
\hline $\begin{array}{l}\text { n-Dodecane } \\
(112-40-3)\end{array}$ & $\begin{array}{c}36.2-46.4 \\
40.3\end{array}$ & & $?$ & 60 & yes*** \\
\hline $\begin{array}{l}\text { n-Hexane } \\
(110-54-3)\end{array}$ & $\begin{array}{c}0.71-0.72 \\
0.8\end{array}$ & 5,000 & no & 25 & no \\
\hline $\begin{array}{l}\begin{array}{l}2-\text { Hexanone } \\
(591-78-6)\end{array} \\
\end{array}$ & $\begin{array}{c}0.57-0.59 \\
0.51\end{array}$ & 5,000 & no & 0.1 & yes \\
\hline $\begin{array}{l}\text { Methylene chloride** } \\
(75-09-2)\end{array}$ & $\begin{array}{c}<0.02-0.061 \\
1.62\end{array}$ & 5,000 & no & 5 & yes \\
\hline \begin{tabular}{|l} 
Nitric oxide \\
$(10102-43-9)$
\end{tabular} & 1.5 & 100 & no & 12.5 & no \\
\hline $\begin{array}{l}\text { Nitrogen dioxide } \\
(10102-44-0)\end{array}$ & $<0.06$ & 50 & no & 1.5 & no \\
\hline $\begin{array}{l}\text { Nitrous oxide } \\
(10024-97-2)\end{array}$ & 763 & & $?$ & 12.5 & yes \\
\hline $\begin{array}{l}\text { Propane nitrile } \\
(107-12-0)\end{array}$ & $\begin{array}{c}5.1-5.3 \\
3.3\end{array}$ & & $?$ & 3 & yes \\
\hline \begin{tabular}{|l} 
Sulfur dioxide \\
$(7446-09-5)$
\end{tabular} & $<0.02$ & 100 & no & 1 & no \\
\hline $\begin{array}{l}\text { Tributyl phosphate } \\
(126-73-8)\end{array}$ & 0.51 & 125 & no & 0.1 & yes \\
\hline \begin{tabular}{|l} 
n-Tridecane \\
$(629-50-5)$
\end{tabular} & $\begin{array}{l}40.1-63 \\
52\end{array}$ & & $?$ & 60 & yes*** \\
\hline $\begin{array}{l}\text { Vinylidene chloride } \\
(75-35-4)\end{array}$ & $\begin{array}{l}<0.02 \\
<0.009\end{array}$ & & $?$ & 0.04 & no \\
\hline
\end{tabular}

* Adopted from the most stringent or available exposure standards/guidelines

** Use $1 / 10$ of CES because of carcinogenicity, teratogenicity, and mutagenicity

*** Counted as a part of NPH, potential exposure to total NPH is expected to exceed $1 / 2$ of CES

CAS - Chemical Abstract Service

CES - Consensus exposure standard

IDLH - Immediately dangerous to life and health

LEL - Lower explosion limit 
$50 \mathrm{ppm}$ has been established by the National Institute for Occupational Safety and Health (NIOSH) for pentanal. Because of the similarities between butanal and pentanal, the TRP recommends using the pentanal value of $50 \mathrm{ppm}$ for butanal.

Table 3.1 also provides a list of available immediately dangerous to life and health (IDLH) values for the target analytes, as reported by NIOSH (NIOSH 1990). The IDLH values represent "the maximum concentration from which, in the event of respirator failure, one could escape within 30 minutes and without experiencing any escape-impairing (e.g., severe eye irritation) or irreversible health effects." NIOSH established these values only for the purpose of respirator selection. Reported concentrations on ammonia in Tank 241-C-103 are found to approach the IDLH value (greater than onehalf of IDLH), but the other target analytes were well below their respective IDLH values. This indicated that ammonia from Tank 241-C-103 may present a potential IDLH concern under a worstcase scenario. The listing of IDLH values in Table 3.1 for carcinogenic compounds such as benzene, 1-3-butadiene, or methylene chloride is only for informational purpose. One must never allow exposure of personnel to carcinogens to the extent which the ambient concentrations could ever reach the IDLH levels.

\subsection{Odor Thresholds}

Workers in the various tank farm areas consistently reported the presence of odors. There has even been an effort to have a reporting system for workers to report odors to HEHF. Certainly, in some cases, the presence of an unusual odor or more intense level of odors routinely encountered may be useful in recognizing abnormal conditions. However, odorous chemicals may not always offer the needed warning to workers after they are in the area. Use of odors to identify hazard, or its absence, can lead to a false sense of security, because odor recognition and detection are very subjective (see Table 3.2), especially when the material responsible for the odor has not been identified. Moreover, the reported concentrations in the head-space vapor of Tank 241-C-103 (Table 3.2) may be much lower than the range of the odor thresholds for most of the target analytes. Individuals vary in their sensitivity to different odorants. A person may be anosmic to one odor and yet hyperosmic to the odor of another similar compound. Such variation occurs in specific anosmia and often is developed by repeated exposure to a particular chemical. Another concern is the problem with olfactory fatigue, which can set in quickly when the person has been exposed for a period of time. All of these can occur in tank farm workers who may have daily exposure to odors of several chemicals. One needs to exercise caution in using the odor thresholds, and take into account in the assessment the presence of chemicals in the ambient air in the work place.

\subsection{Rationale for Using $\mathrm{LD}_{50}$ and $\mathrm{LC}_{50}$ to Evaluate Toxicity Potentials}

Lethal dose $50 \%$ and lethal concentration $50 \%\left(\mathrm{LC}_{50}\right)$ information was used to estimate toxicities of various aldehydes and nitriles. The DQO document for Tank 241-C-103 discusses several approaches to be used when there is not an established exposure limit for a compound. Databases are to be queried for information about the material of interest, e.g., butanal, as well as for information for analogous compounds, such as propanal, pentanal, and hexanal. Various measures of toxicity, including mutagenicity, developmental effects, carcinogenicity, and systemic effects were examined. Values for $\mathrm{LD}_{50}$ and $\mathrm{LC}_{50}$ are commonly used endpoints in initial toxicity assays (Sax and Lewis 1989). 
Table 3.2. Odor Thresholds and Descriptions on Tank 241-C-103 Target Analytes

\begin{tabular}{|c|c|c|c|c|c|}
\hline \multirow[b]{2}{*}{ Chemical } & \multicolumn{3}{|c|}{ "Odor Threshold (ppm) } & \multirow[b]{2}{*}{ Odor Description } & \multirow[b]{2}{*}{$\begin{array}{l}\text { Warning } \\
\text { Properties }\end{array}$} \\
\hline & Detection & Recognition & $\begin{array}{c}\text { Inclusive } \\
\text { Range }\end{array}$ & & \\
\hline Acetone & $\overline{62}$ & 130 & $0.4-800$ & sweet/fruity & $\overline{\text { good }}$ \\
\hline Acetoninile & 160 & & $80.4=1161$ & etherish & poor \\
\hline Iminonia : & 17 & & 10.043753 & puifgentimititing & good \\
\hline Bermene & 61 & 97\% & $10.78-160$ & aromaited w weet & poor \\
\hline 153 Buratiche & $0 \% 5$ & 1.1. & 10.099 . 6 & aromatic frubber & govd: \\
\hline \multicolumn{6}{|l|}{ Butanal } \\
\hline 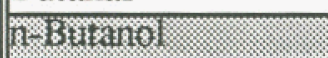 & 122 & 3.8 & $6.05-96 \%$ & swect alleoror & good \\
\hline \multicolumn{6}{|l|}{ Dovecrane } \\
\hline n-Hexane & & & $65-248$ & gasoline & poor \\
\hline 2. I & & & 0,07806085 & sweetpain: & good \\
\hline Metiylene dilorite & 160 & 230 & 1.24406 & sweet & poor \\
\hline \multicolumn{6}{|l|}{ Nitric oxide } \\
\hline Nitrogen dioxide & & & $0.058-0.14$ & bleach & good \\
\hline \multicolumn{6}{|l|}{ Nitrous oxide } \\
\hline PTopane nitrile & T. 6 & & 6.22 & onengaricic & good: \\
\hline Sulfur dioxide & 2.7 & 4.4 & $0.33-5$ & $\begin{array}{l}\text { metallic taste/sharp } \\
\text { irritating }\end{array}$ & good \\
\hline \multicolumn{6}{|l|}{ Cributul phospliate } \\
\hline \multicolumn{6}{|l|}{ 7. Thidecune } \\
\hline Vinylidene chloride & 190 & & & sweet & poor \\
\hline
\end{tabular}

Sources: American Industrial Hygiene Association 1989.

Lewis 1993.

Mine Safety Appliances Company 1994.

NIOSH 1990.

These values often are used as the starting point for establishing exposure standards such as the threshold limit values (TLVs) (ACGIH 1991, 1993). Therefore, the TRP believes that it is appropriate to examine $\mathrm{LD}_{50}$ or $\mathrm{LC}_{50}$ values when exposure limits have not been adequately established. However, the TRP recommends that the $\mathrm{LD}_{50}$ and $\mathrm{LC}_{50}$ must be used with discretion, because the interpretations of these values may be limited by many factors, including route and rapidity of administration, and physiologic status and gender of the experimental animals used. Thus, $\mathrm{LD}_{50}$ and $\mathrm{LC}_{50}$ values were used as one basis to estimate appropriate exposure levels. 


\subsection{Toxicologic Implications of Tentatively Identified Chemicals}

In addition to the analytical information on the compounds recommended by the TRP, Huckaby and Story (1994) also listed in Appendix A of their report some 246 tentatively identified compounds. This extensive list indicated the extremely complex nature of the head-space vapor from Tank 241-C-103. However, there are many uncertainties associated with the identity and concentration of the listed compounds; most were identified on the basis of their retention time and signature recognition (matches and fits) from library spectra typically used in gas chromatography-mass spectrometry (GC-MS). A number of these compounds were either double or multiple entries, and many were listed as mixtures; most were present in relatively low concentrations relative to established exposure standards. Moreover, the complexity of the mixture and the uncertainty of the identifications made it impractical to assess the actual contribution of each of these materials to the potential toxicity of the vapors. Thus, the efforts of the analytical laboratories and the industrial health and safety resources were focused on those chemicals that were deemed to represent the greatest potential for producing toxicologic effects. Working with WHC staff and their consultants during the past year, the TRP reviewed existing analytical data and produced a preliminary list of chemicals of potential toxicologic concern based on concentrations, toxicity, and consistency of data. After a series of evaluations by the TRP, a more refined list of chemicals for analytical validation and further toxicologic evaluation was produced as described previously.

The presence of many other compounds should not be ignored; however, clarification of any biological effects will require additional efforts, because the potential toxicity of mixtures of chemicals cannot be accurately predicted from chemical characterization data alone. It has been shown with a number of complex organic mixtures from tobacco smoke and synthetic fuel processes that the biological effects produced are markedly different from those predicted from the chemical analysis. However, these same studies have shown that mixtures can be biologically characterized using both simple cellular and whole-animal systems.

Until actual biological characterization of tank vapors is performed, there will be uncertainty about the contribution of unidentified constituents as well as the interaction of the chemicals on biological systems. Therefore, the TRP recommends that studies be undertaken to biologically characterize vapors from Tank $241-\mathrm{C}-103$ to ensure that they do not produce unexpected toxic effects. Initial screening studies could be performed in cellular systems, providing some indication of a hitherto unidentified component or interaction among components in a biological system. 



\subsection{Applicable Industrial Hygiene Considerations}

An important application that follows the toxicologic evaluation of chemicals in the tank head space is to provide the WHC Industrial Hygiene Group some basis on which to formulate an exposureassessment strategy (Hawkins et al. 1991). This will be useful to evaluate and control workers' potential exposure to chemicals from working at Tank 241-C-103. The TRP recommends the following considerations in the design of an industrial hygiene exposure-assessment program.

\subsection{Sample Selected Chemicals}

For short-term, nonroutine work activities such as those found in the tank farm, WHC Industrial Hygiene personnel should consider sampling for selected chemicals for the duration of the work period. Compounds of interest may include acetonitrile, ammonia, benzene, nitrous oxide, and NPHs. Quantitative assessment should be sought to better define the exposure risk, to evaluate and ensure workers' protection and regulatory compliance, and to verify the efficacy of available control measures.

\subsection{Evaluate Exposure Standards}

Chemicals with limits of quantitation (LOQ) values given for their RELs warrant attention. For example, new information has become available on 1,3-butadiene as NIOSH updated the exposure limit to $0.19 \mathrm{ppm}$ (LOQ), while the OSHA permissible exposure limit (PEL) (Title 29 CFR 1910) for 1,3-butadiene remains at $1000 \mathrm{ppm}$. Industrial hygienists need to evaluate all available information to determine which exposure standard to use, keeping in mind that workers' protection must be the first and foremost criterion. This approach particularly applies to benzene, 1,3-butadiene, and methylene chloride.

\subsection{Share Information}

Data on the sampling results and toxicity of constituents must be provided to the workers. This should alleviate workers' concern about potential exposure hazard, and will help them understand the importance of prescribed control measures, such as the use of special procedures and/or personal protective clothing. This information-sharing should be part of hazard-communication training, with documentation and, if necessary, follow-up on-the-job training. Sampling results also must be communicated to the medical staff for both medical surveillance and targeted personal medical monitoring.

\subsection{Protect Against (Skin-Designated) Chemicals}

Exposure standards for chemicals such as n-butanol and 2-hexanone carry a "skin" designation in the exposure standards. This designation refers to the potential significant contribution to the overall exposure by the cutaneous route. When potential exposure to the skin-designated chemicals is anticipated, it is advisable to require workers to cover all exposed skin. The choice of gloves for skin 
protection will be important if personnel need to handle parts that are contaminated with the chemicals. One should consult various publications regarding chemical protective clothing. Consider the following examples:

- Chemical Protective Clothing, a two-volume textbook published by the American Industrial Hygiene Association (AIHA)

- Guidelines for the Selection of Chemical Protective Clothing, a two-volume field reference manual published by the American Conference of Governmental Industrial Hygienists

- Manufacturers' publications, such as Best's Guide to Chemical Resistant Best Gloves.

In terms of sampling for personnel exposure, "sniff" sampling may be performed on work equipment and other work surfaces (Ness 1991), particularly for skin-designated chemicals. Sniff sampling using detection devices such as the portable gas chromatograph with flame ionization detector or photo-ionization detector (GC-FID/PID) will be useful. These detection devices do not usually distinguish individual compounds, and therefore only provide qualitative results. However, a GC-FID/PID is an excellent tool to determine whether contamination is present or decontamination is effective. Sniff sampling should target compounds such as n-butanol and 2-hexanone.

\subsection{Consider Ambient Conditions that May Affect Personnel Exposure}

To evaluate workers' exposure in outdoor work (as it is typically found in the tank farm areas), it is important to consider the meteorological data or ambient conditions in the periods during which exposure sampling is conducted. In general, the magnitude of exposure is dependent upon the distance or proximity of the workers from the source of chemical release. Dispersion of chemical vapors or aerosols depends on wind speed and directions, barometric pressure, ambient temperature, and relative humidity. Terrain features and existing barriers in the local area around the tank farm also can affect the dispersion patterns of the airborne chemical contaminants. One needs to recognize the importance of meteorological conditions in order to evaluate workers' exposure and to include these conditions in the decisions for workers' protection. It is also important to note that meteorological conditions may change during a work period, such that the meso-scale (immediate area) meteorological conditions should be monitored continuously. 


\subsection{Sentinel Compounds}

The data used for toxicologic evaluation were obtained from the head space of Tank 241-C-103. These data thus represent the highest concentrations that would be encountered in the work place. From a pragmatic point of view, it would be desirable to measure levels in the breathing zone of workers around the tank. Attempts at such measurements by the WHC Industrial Hygiene Group have generally shown little or no apparent material being present. Releases of vapors from the head space seem to occur sporadically, so unless the measurements coincided with releases, failure to detect vapor components would be likely. However, if releases occur, the concentrations of the various components of the vapor are likely to be significantly lower in the vicinity of the workers' breathing zone than in the head-space vapor itself.

Materials for which the maximum concentration in the head space is near the limit of detection (for example, 1,3-butadiene and vinylidene chloride) pose special challenges for the industrial hygienist trying to measure their concentrations in the work place. Therefore, these compounds may be difficult to retain on a list of compounds of toxicologic concern. Yet, they are considered carcinogens by NIOSH and thus, the RELs are essentially the LOQ, even though exposure standards set by other groups may be significantly higher. The concentration of benzene in the vapor is also low and difficult to detect in the breathing zone of workers around Tank 241-C-103.

To ensure that carcinogenic compounds in very low concentrations are not missed, a limited number of chemicals (perhaps three) should serve as sentinel compounds to be monitored routinely. Compounds should be selected based on their relatively high concentrations in the head space and their ability to be easily detected in the event of a release. If these sentinel compounds are detected in the working area at concentrations above an action level, one would assume that other toxic materials which are present proportionately at lower levels in the head-space vapor also are being released at levels of concern; specific sampling targeted to other toxic materials may be necessary. In general, actions to protect against these sentinel compounds would also protect against the other toxic materials. For example, ammonia, nitrous oxide, and tridecane are found at relatively high concentrations and can be easily measured. Monitoring for these materials in the work place could be accomplished easily and actions taken if the levels exceed an established warning level. Taking measures to protect against undue exposures to these compounds should then prevent undue exposures to other compounds of toxicologic concern that have been identified in the head-space vapor. This approach would seem to offer a practical and economic way to protect workers while allowing the necessary work to be performed.

An example might serve to illustrate how such a system might work. For simplicity, the following example considers only two materials, a sentinel compound and a carcinogen. The concentration of ammonia in the head space is about $300 \mathrm{ppm}$ and that of benzene is $0.33 \mathrm{ppm}$. For this example, we have used the short-term exposure limit for benzene to illustrate the possible use of a sentinel compound because there is no expectation that workers would be working for $8 \mathrm{hr} / \mathrm{d}$ where releases were occurring. The short-term (15-min) exposure limit for benzene is $1.0 \mathrm{ppm}$. Thus, following the procedure specified in the DQO, a level of $0.1 \mathrm{ppm}(0.1 \mathrm{x}$ short-term exposure limit) would be considered as an action level. Concentrations as low as $0.1 \mathrm{ppm}$ outside of the tank would have to be detected, a difficult level to measure. However, if we assume that the ratio of benzene to ammonia in the breathing zone outside of the tank is the same as in the head space, we can arrive at a level of ammonia that would serve as a warning for benzene. The concentration of benzene would need to be 
3.3-fold less outside of the tank than it is inside in order to meet the 0.01-ppm designated level $(0.33 \mathrm{ppm} / 3.3=0.1)$. Thus, a concentration of ammonia in the breathing zone $1 / 3.3$ of that in the head space, or $90 \mathrm{ppm}$, should be indicative of a benzene level of $0.1 \mathrm{ppm}$, warning that action should be taken. However, the short-term exposure limit for ammonia is $35 \mathrm{ppm}$, so even if that value is met, the exposure to benzene would be less than $40 \%$ of the $0.1-\mathrm{ppm}$ limit. Because prolonged exposure to ammonia would be limited to one-half of its TLV of $12.5 \mathrm{ppm}$, even long-term benzene exposure wouldn't exceed $0.01 \mathrm{ppm}[0.1 \times 0.1 \mathrm{ppm}$, the REL for 8-hr time-weighted average (TWA)]. Thus, using a sentinel compound such as ammonia would still offer a high degree of protection while permitting detection of releases into the work place.

Table 6.1 compares the use of ammonia, nitrous oxide, and tridecane as sentinel compounds for benzene and 1,3-butadiene. The calculations used in the table show that, for Tank 241-C-103, benzene would serve as the driving force for determining the level of sentinel compound(s) at which protective action would be taken. It can also be seen that these levels are influenced by both the level of the carcinogen of interest and the compounds being considered as sentinels.

From a practical standpoint, sentinel compound sampling will save time and resources for evaluation of workers' exposure. One needs to understand that sentinel sampling does not and should not preclude baseline and periodic sampling as required by OSHA regulations. Sentinel sampling can be done after a baseline for all the target chemicals present has been established within some level of confidence. We merely suggest that when confidence has been established on the expected concentrations and ratios among the various target chemicals, one may choose to sample fewer compounds that can represent the presence of the others. A baseline may change in time as work procedures may change, or exposure conditions may be improved either by engineering controls or mitigation/reduction of the hazards. At that time, a new baseline sampling may be performed. Periodic sampling to verify the validity of the current baseline should be performed from time to time.

Table 6.1. Use of Sentinel Compounds to Monitor for Carcinogens in Vapor from Tank 241-C-103

\begin{tabular}{|c|c|c|c|c|c|}
\hline & & & \multicolumn{3}{|c|}{$\begin{array}{l}\text { Sentinel Conc. Equiv. }{ }^{* *} \text { to } 0.1 \text { TLV for } \\
\text { Carcinogen }\end{array}$} \\
\hline Carcinogen & $\begin{array}{c}\text { Conc. in C-103 } \\
\text { (ppm) }\end{array}$ & $\begin{array}{c}0.1 \overline{T L V} \\
(\mathrm{ppm})\end{array}$ & Ammonia & $\mathrm{N}_{2} \mathrm{O}$ & Tridecane \\
\hline Benzene & 0.33 & $0.1^{* * * *}$ & 90 & $\overline{230}$ & $\overline{15}$ \\
\hline 1.3-Butadiene & 0.06 & 0.02 & 109 & 277 & 18.5 \\
\hline
\end{tabular}

* Highest reported concentrations from Sample Job 7B

** Based on concentrations in Tank 241-C-103 head-space vapor of 300, 763, and $52 \mathrm{ppm}$ for ammonia, nitrous oxide, and tridecane, respectively.

*** Based on 15-min short-term exposure limit for benzene 


\subsection{Conclusions}

Acetone, hexane, nitric oxide, nitrogen dioxide, and sulfur dioxide do not exceed one-half of their respective consensus exposure standards. Although there is no such standard for butanal, the butanal concentrations do not exceed the consensus exposure standards for pentanal, a similar compound. The concentration of the carcinogen vinylidene chloride does not exceed one-tenth of its consensus exposure standard. These compounds should not raise unacceptable toxicologic concern.

The concentrations of ammonia, nitrous oxide, tributyl phosphate, acetonitrile, n-butanol, 2-hexanone, propane nitrile, benzene, methylene chloride, NPHs, and 1,3-butadiene are greater than one-half of the REL for noncarcinogens or greater than one-tenth of the REL for carcinogens. Therefore, they should receive continued consideration. Methylene chloride may be a sampling and analysis artifact; further clarification is needed from the laboratories before this compound can be ruled out.

Due to lack of consensus exposure standards for butanal and NPHs, particularly dodecane and tridecane, rationale has been given to treat the NPHs as a group and to set a consensus exposure standard for dodecane and tridecane at $120 \mathrm{ppm}$.

For those compounds that merit continued consideration, the TRP believes that an exposure assessment strategy should be developed that includes, at minimum, area and personal sampling, hazard communication and training, medical monitoring, and record-keeping. Documentation of the exposure assessment strategy will be critical. In the absence of sufficient engineering or administrative controls, appropriate personal protection shall be used for personnel working in the area. The industrial safety staff should also consider mitigation strategies to prevent potential release of these chemicals into the environment.

Meteorological data should be continuously collected when personnel are working in the immediate area or when exposure sampling is performed. The ambient conditions may change during a given work period. Such changes may influence decisions on workers' protection in the tank farm areas.

A method for using sentinel compounds to monitor potential worker exposure is suggested.

Biological characterization of the vapors is recommended.

The following is a revised list of chemicals targeted for toxicologic evaluation (as of August 6, 1994), and includes Chemical Abstract Service (CAS) references (see Table 7.1):

- Acetonitrile (CAS 75-05-8)

- Ammonia (CAS 7664-41-7)

- Benzene (CAS 71-43-2)

- 1,3-Butadiene (CAS 106-99-0)

- n-Butanol (CAS 71-36-3) 
- 2-Hexanone (CAS 591-78-6)

- Methylene chloride (CAS 75-09-2)

- Nitrous oxide (CAS 10024-97-2)

- NPHs (dodecane and tridecane) (CAS 112-40-3 \& 629-50-5)

- Propane nitrile (CAS 107-12-0)

- Tributyl phosphate (CAS 126-73-8).

Table 7.1. Summary List of Targeted Chemicals for Toxicologic Evaluation as of August 6, 1994

\begin{tabular}{|c|c|c|c|c|c|c|c|}
\hline \multirow{2}{*}{ Compound } & \multirow{2}{*}{ CAS } & \multirow{2}{*}{$\begin{array}{l}\text { Sample } \\
\text { Type }\end{array}$} & \multirow{2}{*}{$\begin{array}{c}\text { Reported } \\
\text { Concentration } \\
\text { (ppmv) }\end{array}$} & \multicolumn{2}{|c|}{ CES (ppm) } & \multirow{2}{*}{$\begin{array}{l}\text { CES } \\
\text { Sources }\end{array}$} & \multirow{2}{*}{$\begin{array}{l}\text { Expected } \\
\text { Health Effects }\end{array}$} \\
\hline & & & & 8-hour TWA & STEL & & \\
\hline Acetonitrile & $75-05-8$ & $\begin{array}{c}\text { SLMMA } \\
\text { TST }\end{array}$ & $\begin{array}{c}19.3-19.4 \\
8.8 \\
\end{array}$ & $\overline{20}$ & $\overline{60}$ & $\mathrm{x}, \mathrm{y}$ & Brain tumors; lung and bowel cancer \\
\hline Ammonia & $7664-41-7$ & $\begin{array}{l}\text { Sorbent } \\
\text { Trap }\end{array}$ & 304 & 25 & 35 & $x, y$ & Respiratory and eye irritation \\
\hline $\begin{array}{l}\text { Benzene } \\
\text { (A2) }\end{array}$ & $71-43-2$ & $\begin{array}{l}\text { SUMMA } \\
\text { TST }\end{array}$ & $\begin{array}{c}<0.01-0.33 \\
0\end{array}$ & $0.1 / \mathrm{LOQ}$ & $\begin{array}{c}1(\mathrm{c}) \\
(15 \mathrm{~min})\end{array}$ & $x, y$ & Leukemia \\
\hline $\begin{array}{c}\text { 1,3-Butadiene } \\
\text { (A2) }\end{array}$ & $106-99-0$ & SUMMA & $<0.05-0.06$ & $0.19 / \mathrm{LOQ}$ & & $\mathrm{x}$ & $\begin{array}{l}\text { Hematopoietic cancer; teratogenic and } \\
\text { reproductive effects }\end{array}$ \\
\hline n-Butanol & $71-36-3$ & $\begin{array}{l}\text { SLMMA } \\
\text { TST }\end{array}$ & $\begin{array}{l}13.1 \\
28.4\end{array}$ & $50(\mathrm{c})(\mathrm{s})$ & & $x, y$ & $\begin{array}{l}\text { Eye and mucous membrane irritation; } \\
\text { CNS depression }\end{array}$ \\
\hline $\begin{array}{l}\text { 2-Hexanone } \\
(\mathrm{MnBK})\end{array}$ & $591-78-6$ & $\begin{array}{l}\text { SUMMA } \\
\text { TST }\end{array}$ & $\begin{array}{c}0.57-0.59 \\
0.51\end{array}$ & 1 & & $\mathrm{x}$ & $\begin{array}{l}\text { Irritation; liver, kidney, } \\
\text { and nervous system effects }\end{array}$ \\
\hline $\begin{array}{c}\text { Methylene } \\
\text { chloride (A2) }\end{array}$ & $75-09-2$ & $\begin{array}{l}\text { SUMMA } \\
\text { TST }\end{array}$ & $\begin{array}{c}<0.02-0.061 \\
1.62\end{array}$ & LOQ & & $\mathrm{x}$ & $\begin{array}{l}\text { Potential for cancer; tumors of the lung, liver, } \\
\text { salivary, and mammary glands in animals }\end{array}$ \\
\hline Nitrous oxide & $10024-97-2$ & SUMMA & 763 & & 25 & $\mathrm{x}$ & $\begin{array}{c}\text { Reproductive system effects and decreases in } \\
\text { audiovisual performance }\end{array}$ \\
\hline Dodecane & $112-40-3$ & $\begin{array}{l}\text { OVS } \\
\text { CCT }\end{array}$ & $\begin{array}{c}36.2-46.4 \\
40.3\end{array}$ & 120 & & $w$ & Skin and nervous system effects \\
\hline Tridecane & $629-50-5$ & $\begin{array}{l}\text { OVS } \\
\text { CCT }\end{array}$ & $\begin{array}{c}40.1-63 \\
52\end{array}$ & 120 & & w & Skin and nervous system effects \\
\hline Propane nitrile & $107-12-0$ & $\begin{array}{l}\text { SLMMA } \\
\text { TST }\end{array}$ & $\begin{array}{c}5.1-5.3 \\
3.3\end{array}$ & 6 & & $\mathrm{x}$ & $\begin{array}{l}\text { Hepatic, renal, respiratory, cardiovascular, } \\
\text { gastrointestinal, and nervous system effects }\end{array}$ \\
\hline $\begin{array}{c}\text { Tributyl } \\
\text { phosphate } \\
\end{array}$ & $126-73-8$ & $\mathrm{CCT}$ & 0.51 & 0.2 & & $x$ & $\begin{array}{c}\text { Pulmonary irritation; moderate excitation of } \\
\text { nervous svstem in animals }\end{array}$ \\
\hline
\end{tabular}
A2 Suspected human carcinogen
(c) Ceiling
(s) Skin designation
(p) Peak concentration
w TRP-derived guideline
$X$ NIOSH REL
y ACGIH TLV
z OSHA PEL
CCT Carbo C Trap

LOQ Limit of quantitation. For carcinogenic materials,

NIOSH recommends $L O Q$ as the desired limit.

OVS OSHA verstile sampler

STEL Short-term exposure limit

SUMMA A registered trademark of evacuated sampler by Molectrics, Inc.. Cleveland, Ohio.

TST Triple-sorbent tube

TWA Time-weighted average 


\subsection{References}

Title 29, Code of Federal Regulations, Part 1910, Section 1000, Subpart Z. Air Contaminants. U.S. Department of Labor, Occupational Safety and Health Administration. Washington, D.C.

American Conference of Governmental Industrial Hygienists (ACGIH). 1991. Documentation of the Threshold Limit Values and Biological Exposure Indices, Sixth Edition. ACGIH, Cincinnati, Ohio.

American Conference of Governmental Industrial Hygienists (ACGIH). 1993. Threshold Limit Values for Chemical Substances and Physical Agents and Biological Exposure Indices. ACGIH, Cincinnati, Ohio.

American Industrial Hygiene Association. 1989. Odor Thresholds for Chemicals with Established Occupational Health Standards. American Industrial Hygiene Association, Fairfax, Virginia.

Hawkins, N.C., S.K. Norwood, and J.C. Rock. 1991. A Strategy for Occupational Exposure Assessment. American Industrial Hygiene Association. Fairfax, Virginia.

Huckaby, J.L. and M.S. Story. 1994. Vapor Characterization of Tank 241-C-103. WHC-EP-0780. Westinghouse Hanford Company, Richland, Washington.

Lewis, R.J. 1993. Hazardous Chemicals Desk Reference. Third Edition. Van Nostrand Reinhold Company, New York, New York.

Mahlum, D.D. and J.Y. Young. 1993. Waste Tank Safety Program, Annual Status Report for FY 1993, Task 5: Toxicology and Epidemiology. PNL-8993. Pacific Northwest Laboratory, Richland, Washington.

Mine Safety Appliances Company. 1994. 1994 Response Respirator Selector. Pittsburgh, Pennsylvania.

National Institute for Occupational Safety and Health. 1977. Occupational Diseases - A Guide to Their Recognition. U.S. Department of Health and Human Services, Cincinnati, Ohio.

National Institute for Occupational Safety and Health. 1990. NIOSH Pocket Guide to Chemical Hazards. U.S. Department of Health and Human Services, Cincinnati, Ohio.

National Institute for Occupational Safety and Health. 1992. NIOSH Recommendations for Occupational Safety and Health - Compendium of Policy Documents and Statements. U.S. Department of Health and Human Services, Cincinnati, Ohio.

Ness, S.A. 1991. Air Monitoring for Toxic Exposures - An Integrated Approach. Van Nostrand Reinhold Company, New York, New York.

Osborne, J.W. and J.L. Huckaby. 1994. Program Plan for the Resolution of Tank Vapor Issues. WHC-EP-0562. Westinghouse Hanford Company, Richland, Washington. 
Osborne, J.W., J.L. Huckaby, T.P. Rudolph, E.R. Hewitt, D.D. Mahlum, J.Y. Young, and C.M. Anderson. 1994. Tank 241-C-103 vapor and Gas Sampling Data Quality Objectives. WHC-EP-0774. Westinghouse Hanford Company, Richland, Washington.

Sax, N.I. and R.J. Lewis. 1989. Dangerous Properties of Industrial Materials. Seventh Edition. Van Nostrand Reinhold Company, New York, New York. 


\section{Distribution}

No. of

Copies

Offsite

12 DOE/Office of Scientific and Technical Information

Onsite

2 DOE Richland Operations Office

R.F. Christensen, S7-54

S.O. Branch, S7-54

12 Westinghouse Hanford Company

H. Babad, S7-30

R.B. Conrad, H5-09

J.S. Davis, H4-64

G.T. Dukelow, S7-15

K.A. Gasper, G3-21

E.R. Hewitt, R3-01

J.L. Huckaby, S7-15

G.D. Johnson, S7-15

T.J. Kelley, N3-10

J.W. Osborne, S7-15

M.A. Payne, S7-14

D.A. Turner, S7-15

Northwest Instrument Systems, Inc.

M.S. Story, H0-57

MacTech

S.T. Murff, S7-73
No. of

Copies

Bechtel Hanford, Inc.

T.P. Rudolph, R3-54

Hanford Environmental Health Foundation

J.A. Calcagni, H1-02

60 Pacific Northwest Laboratory

K.J. Allwine, K6-11

R.M. Bean, P8-08

L.A. Braby, P8-47

A.L. Brooks, P7-53

B.J. Chou, K4-10

T.R.W. Clauss, P8-08

J.R. Decker, K4-16

J.A. Dill, K4-16

J.S. Fruchter, K6-96

S.C. Goheen, P8-08 (10)

R.J. Hall, K8-28

B.L. Harper, P7-82

M.F. Jarvis, K3-54

B.M. Johnson, K1-78

B.D. Lerner, P8-08

M.W. Ligotke, P7-59

R.B. Lucke, P8-08

C.C. Lumetta, P7-58

D.D. Mahlum, P7-56

B.D. McVeety, K6-63

P.J. Mellinger, P7-22

H.S. Miley, P8-08

E.W. Morgan, K4-10

J.E. Morris, P7-53

D.A. Nelson, P8-38

J.F. Park, P7-52

K.H. Pool, P8-44

R.K. Quinn, K1-73 
No. of

\section{Copies}

R.A. Renne, K4-13

G.F. Schieffelbein, P8-38

P.R. Seesing, K6-96

D.L. Springer, P7-56

B.D. Thrall, P7-56

R.A. Walters, K1-50

R.E. Weller, P7-52

J.Y. Young, K4-16 (10)

Publishing Coordination

Technical Report Files (5) 